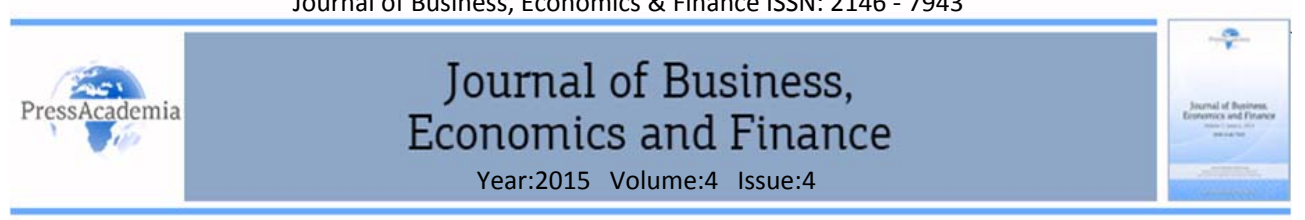

\title{
EXPANDING EFFECTS OF MILITARY EXPENDITURES ON EXTERNAL DEBT IN DEVELOPING COUNTRIES
}

DOI: 10.17261/Pressacademia.2015414532

\author{
Selcuk Cagri Esener ${ }^{1}$, Evren Ipek ${ }^{2}$ \\ ${ }^{1}$ Bandırma Onyedi Eylul University, Turkey. Email: esener@balikesir.edu.tr \\ ${ }^{2}$ Bandırma Onyedi Eylul University, Turkey. Email: eipek@balikesir.edu.tr
}

\section{Keywords}

Military expenditure, external debt, panel data, developing countries

JEL Classification F52, H63, C23

\section{ABSTRACT}

The aim of this study is to investigate the effects of military expenditures on external debt with other variables like GDP growth, fixed capital formation and openness. The empirical analyses are utilized by using annual panel data for 36 developing countries and by following the methodologies of "Pooled OLS Model" and "Dynamic Panel Estimations". The sample period covers the years between 1996 and 2013. The estimation results indicate that a change in military expenditure affects external debt positively in developing countries concerned.

\section{INTRODUCTION}

The role of military expenditure in external debt is important due to the potential unfavorable effects of external debt on the economic performance. Deterioration in terms of trade, overvaluation of domestic currency and slowdown in economic growth are the examples of these adverse effects of excessive external debt accumulation (Smyth and Narayan, 2009: p. 235). There are three main channels that defence expenditure affect external debt. Firstly, the consumption of arms causes a reduction in the available resources that may be directed to the import of intermediate and investment goods that will stimulate long run growth especially in developing countries with scarce foreign exchange. Secondly, the military expenditure exceeding the government revenues cause budget deficits. And these budget deficits have to be financed by foreign borrowing if the country is in a lack of domestic funding opportunities. Lastly, domestic production of arms may create demand for high-tech imported intermediate inputs and machinery, and hence increase foreign exchange demand to consume these products (Smyth and Narayan, 2009: p. 239; Dunne et al., 2004a: p. 181). However, defence expenditures can create positive externalities by contributing to modernization, leading to technological spillover effects, building physical infrastructure and supporting modernization of healthcare. Through these positive externalities, defence spending can have a contributing effect on the productivity (Ahmed, 2012: p. 491). Impact of military expenditure on macroeconomic indicators has attracted the attention of economics researchers both from developed and 
developing countries, since the military expenditure is one of the most important expenditure items in the central government budgets and it can affect future economic performance through its considerable influence on the level of indebtedness (Ahmed, 2012: p. 487). In the review of the empirical literature, it is seen that the majority of the empirical researches have focused on the relationship between military expenditure and growth. Relatively few studies have investigated the effect of military expenditure on external debt. However, understanding of the contribution of defence spending in external debt stock is crucial for policymakers of developing economies. Moreover, the existent literature predominantly consists of empirical studies using time series methods for single countries.

It is detected that there are few studies employing panel data methods for particular regions. Because of these reasons, this study aims to empirically investigate the military expenditure and external debt nexus for a group of developing economies by using panel data methodologies and by this way enrich the empirical literature in this field. Our main objective is to contribute to the related literature by applying panel data methodologies and by exploring the debate for a group of developing countries from different regions of the world rather than selecting the country group from a particular geographical region. For this purpose, the linkage between military expenditure and external debt is investigated for 36 countries by using annual panel data for the period between 1996 and 2013. The empirical investigations are carried out by employing the methodologies of "Pooled OLS Models" and "Dynamic Panel Estimations".

The remainder of paper is organized as follows: The second part includes the recent literature that empirically investigates the relationship between military expenditure and external debt. In the third part, the data and methodology that will be used in empirical applications are presented. The empirical results are submitted in the fourth part; followed by conclusion and suggestions in the last part.

\section{LITERATURE REVIEW}

This section of the paper reviews the attempts, which aimed to determine the impact of defence expenditure on external debt, in the related literature. The previous studies, evaluating the impact of military expenditure on external debt, are summarized in Table 1 and they can be categorized as those using time series for single countries [(Dunne et al. (2004a), Sezgin (2004), Karagöl (2005), Karagöl (2006), Narayan and Narayan (2008), Karagöl and Turhan (2008), Wolde-Rufael (2009), Zaman et al. (2012), Shahbaz et al. (2013)] and those applying panel data methods [Dunne et al. (2004b), Symth and Narayan (2009), Ahmed (2012)]. The second group is more relevant to our paper based on methodological terms. Dunne et al. (2004a), empirically analyze the effect of defence expenditure on external debt for Brazil, Argentina and Chile by using autoregressive distributed lag (ARDL) model. Estimated model includes independent variables such as defence expenditure, GDP, exports, reserves and interest rate. The data period is between 1970 and 2000 for Argentina and Chile; 1971 and 2000 for Brazil respectively. According to the empirical results, military expenditure has positive effects on external debt in Chile, while there is no empirical evidence about this relationship for Argentina and Brazil. 
In another study of Dunne et al. (2004b), defence expenditure-external debt debate is examined in a panel that gathered 11 small industrializing economies (Chile, Brazil, Argentina, Venezuela, South Africa, Malaysia, Philippines, India, Pakistan, South Korea, Turkey), by using panel data methods. The explanatory variables of the external debt model are determined as military burden, GDP growth, international reserves and exports. The sample period is identified from 1960 to 2000 and the study provides estimates with fixed effects and random effects models in addition to generalized method of moments (GMM). It is determined that the military burden has a positive effect on external debt.

Sezgin (2004) investigates defence-debt nexus for Turkey. The period of the empirical analysis is between 1979 and 2000, and the external debt is tried to be explained with the explanatory variables of GDP, defence expenditure and balance of trade. The results of Engle-Granger cointegration test show that the long run relation between defence expenditure and external debt is significantly negative.

One of the popular papers, related to defence expenditure-external debt relationship, for Turkish economy belongs to Karagöl (2005). The external debt is tried to be explained by defence expenditure in a bivariate model. The study employs Johansen cointegration procedure, Granger causality analysis and impulse response function (IRF) between the years of 1955 and 2000. The cointegration analysis shows that there is a long run relationship between defence expenditure and external debt; and the impact of defence expenditure is positive. This positive effect is supported by the IRF results. Furthermore, Granger causality test represents a unidirectional causality from defence expenditure to external debt. In the case of Turkey, Karagöl (2006) investigates the relationship between defence expenditure and external debt by including gross national product (GNP) and investments in the Karagöl (2005)'s model. In the empirical analysis, the methodology of IRF and variance decomposition is applied with the annual data of the years between 1960 and 2002. Empirical results show that defence expenditures increase Turkey's external debt significantly. 
Table 1: Empirical Studies

\begin{tabular}{|c|c|c|c|c|c|}
\hline Researcher & Period & Country & $\begin{array}{l}\text { Explanatory } \\
\text { Variables of } \\
\text { External Debt }\end{array}$ & Method & Empirical Results \\
\hline $\begin{array}{l}\text { Dunne et al. } \\
(2004 a)\end{array}$ & $\begin{array}{l}\text { 1970-2000 } \\
\text { (Argentina } \\
\text { and Chile); } \\
\text { 1971- 2000 } \\
\text { (Brazil) }\end{array}$ & $\begin{array}{l}\text { Brazil, } \\
\text { Argentina, } \\
\text { Chile }\end{array}$ & $\begin{array}{l}\text { Defence } \\
\text { Expenditure, GDP, } \\
\text { Interest Rate, } \\
\text { Exports, Reserves }\end{array}$ & ARDL Model & Positive Effect \\
\hline $\begin{array}{l}\text { Dunne et al. } \\
(2004 b)\end{array}$ & $1960-2000$ & $\begin{array}{l}11 \text { Small } \\
\text { Industrializin } \\
\text { g Economies }\end{array}$ & $\begin{array}{l}\text { Military Burden, } \\
\text { GDP Growth, } \\
\text { International } \\
\text { Reserves, Exports }\end{array}$ & $\begin{array}{l}\text { Fixed Effect } \\
\text { Models, Random } \\
\text { Effect Models, } \\
\text { GMM } \\
\end{array}$ & Positive Effect \\
\hline $\begin{array}{l}\text { Sezgin } \\
(2004)\end{array}$ & $1979-2000$ & Turkey & $\begin{array}{l}\text { Defence } \\
\text { Expenditure, GDP, } \\
\text { Balance of Trade }\end{array}$ & $\begin{array}{l}\text { Engle-Granger } \\
\text { Cointegration } \\
\text { Test }\end{array}$ & Negative Effect \\
\hline $\begin{array}{l}\text { Karagöl } \\
\text { (2005) }\end{array}$ & $1955-2000$ & Turkey & $\begin{array}{l}\text { Defence } \\
\text { Expenditure }\end{array}$ & $\begin{array}{l}\text { Johansen } \\
\text { Cointegration } \\
\text { Test, Granger } \\
\text { Causality Test }\end{array}$ & $\begin{array}{l}\text { Positive Effect } \\
\text { Unidirectional causality } \\
\text { from military expenditure } \\
\text { to external debt }\end{array}$ \\
\hline $\begin{array}{l}\text { Karagöl } \\
\text { (2006) }\end{array}$ & $1960-2002$ & Turkey & $\begin{array}{l}\text { Defence } \\
\text { Expenditure, } \\
\text { GNP, } \\
\text { Investment }\end{array}$ & $\begin{array}{l}\text { Johansen } \\
\text { Cointegration } \\
\text { Test, IRF, } \\
\text { Variance } \\
\text { Decomposition }\end{array}$ & Positive Effect \\
\hline $\begin{array}{l}\text { Narayan \& } \\
\text { Narayan } \\
(2008)\end{array}$ & $1970-2005$ & Fiji Islands & $\begin{array}{l}\text { Military } \\
\text { Expenditure, } \\
\text { GDP }\end{array}$ & $\begin{array}{l}\text { Bound Test, } \\
\text { ARDL Model, } \\
\text { FMOLS, DOLS }\end{array}$ & Positive Effect \\
\hline $\begin{array}{l}\text { Karagöl \& } \\
\text { Turhan } \\
(2008)\end{array}$ & $1960-2002$ & Turkey & $\begin{array}{l}\text { Defence } \\
\text { Expenditure, } \\
\text { Dummy Variables }\end{array}$ & $\begin{array}{l}\text { Johansen } \\
\text { Cointegration } \\
\text { Test, IRF }\end{array}$ & Positive Effect \\
\hline $\begin{array}{l}\text { Wolde- } \\
\text { Rufael } \\
\text { (2009) }\end{array}$ & $1970-2005$ & Ethiopia & $\begin{array}{l}\text { Military } \\
\text { Expenditure, } \\
\text { GDP }\end{array}$ & $\begin{array}{l}\text { Bound Test, } \\
\text { ARDL Model, } \\
\text { Granger and } \\
\text { Toda Yamamoto } \\
\text { Causality Tests }\end{array}$ & $\begin{array}{l}\text { Positive Effect } \\
\text { Unidirectional causality } \\
\text { from military expenditure } \\
\text { to external debt }\end{array}$ \\
\hline $\begin{array}{l}\text { Symth \& } \\
\text { Narayan } \\
(2009)\end{array}$ & $1988-2002$ & $\begin{array}{l}\text { Oman, Iran, } \\
\text { Yemen, } \\
\text { Syria, } \\
\text { Jordan, } \\
\text { Bharain, }\end{array}$ & $\begin{array}{l}\text { Defence } \\
\text { Expenditure, GDP }\end{array}$ & $\begin{array}{l}\text { Panel } \\
\text { Cointegration }\end{array}$ & Positive Effect \\
\hline $\begin{array}{l}\text { Zaman et } \\
\text { al. } \\
(2012)\end{array}$ & $1980-2009$ & Bangladesh & Military Expenditure & $\begin{array}{l}\text { Engle-Granger } \\
\text { Cointegration } \\
\text { Test, ECM, } \\
\text { Granger } \\
\text { Causality Test }\end{array}$ & $\begin{array}{l}\text { Positive Effect } \\
\text { Unidirectional causality } \\
\text { from external debt to } \\
\text { military expenditure }\end{array}$ \\
\hline $\begin{array}{l}\text { Ahmed } \\
(2012)\end{array}$ & $1988-2007$ & $\begin{array}{l}25 \text { Sub- } \\
\text { Saharan } \\
\text { African } \\
\text { Countries }\end{array}$ & $\begin{array}{l}\text { Military } \\
\text { Expenditure, GDP } \\
\text { Exports, Imports, } \\
\text { Balance Of Trade, }\end{array}$ & $\begin{array}{l}\text { FMOLS, DOLS, } \\
\text { DFE }\end{array}$ & Positive Effect \\
\hline $\begin{array}{l}\text { Shahbaz et } \\
\text { al. (2013) }\end{array}$ & $1973-2009$ & Pakistan & $\begin{array}{l}\text { Military } \\
\text { Expenditure, } \\
\text { GDP per capita, } \\
\text { Investment }\end{array}$ & $\begin{array}{l}\text { IRF, Bound test, } \\
\text { ARDL Model, } \\
\text { Granger } \\
\text { Causality Test }\end{array}$ & $\begin{array}{l}\text { Positive Effect } \\
\text { Bidirectional causality } \\
\text { between external debt } \\
\text { and military expenditure }\end{array}$ \\
\hline
\end{tabular}


One other study, focusing on Turkish economy, is conducted by Karagöl and Turhan (2008). Their empirical analysis is for the period of 1960-2002. It is aimed to explain the external debt with three explanatory variables, which are defence expenditure, election dummy variable and political color dummy variable. They adopt Johansen cointegration procedure and IRF methodology, and finally report a positive relationship between the military expenditure and external debt.

Another single country analysis is carried out by Narayan and Narayan (2008) for Fiji Islands. The study investigates the relationship between debt, GDP and military expenditure for the period of 1970-2005. They conduct bound test for cointegration and use ARDL model, fully modified ordinary least squares (FMOLS), dynamic ordinary least squares (DOLS) and ordinary least squares (OLS) to estimate the long run and short run effects. Their empirical results indicate a cointegration relationship between the related variables and a significantly positive long run effect of military expenditure on external debt.

Wolde-Rufael (2009) contributes to the relevant literature by examining the impact of defence expenditure on the external debt of Ethiopia, a least developed country that is also one of the severely indebted low-income countries. Military expenditure and GDP are identified as determinants of external debt. The empirical investigations for the period of 1970-2005 are carried out by using the bounds test approach for cointegration and Granger causality tests. Empirical results reveal a long run and a causal relationship between external debt, defence spending and income. Defence spending is found to have a positive and a significant impact on the stock of external debt. Moreover, Granger causality tests indicate a unidirectional causality from military expenditure to external debt.

Symth and Narayan (2009) analyze the effects of military expenditure on external debt for six Middle Eastern countries as follows; Oman, Syria, Yemen, Bahrain, Iran and Jordan by using annual panel data for the period of 1988-2002. The external debt model is estimated within the independent variables of defence expenditure and GDP. Panel unit root and panel cointegration methodology are implemented in the empirical analyses. They find that defence expenditure has a positive effect on external debt both in the long run and in the short run period.

In a related study, Zaman et al. (2012) investigate the connection between external debt and defence spending in Bangladesh. In investigating the defence-external debt nexus over the period of 1980-2009, they employ Engle-Granger cointegration test, error correction model (ECM) and Granger causality analysis. They find that military burden has a positive effect on external debt. Furthermore, empirical evidence puts forth a unidirectional causality running from military spending to external debt.

Ahmed (2012) contributes to this literature with a multi-country panel data analysis. He investigates the relationship between military expenditure and external debt by including 25 sub-Saharan African countries in his study. In the empirical investigation, three advanced panel techniques FMOLS, DOLS and dynamic fixed effect (DFE) are employed for 
the period of 1988-2007. In the analysis, the external debt is explained by independent variables such as military expenditure, GDP, export, import and balance of trade. According to the empirical results, there is a significantly positive effect of military expenditures on the external debt.

More recently, Shahbaz et al. (2013) carried out a time series analysis to investigate the relationship between external debt, military expenditure, investment and GDP. Their empirical analysis includes the period of 1973-2009 of Pakistan economy. ARDL model, Granger causality analysis and IRF are employed to investigate the relationship between these parameters. They find that military expenditure has a positive impact on external debt and there is bidirectional causality between military expenditure and external debt.

\section{MODEL, DATA AND ESTIMATION METHOD}

\subsection{Model and Data}

The aim of this paper is to investigate the impacts of military expenditure on external debt by including additional independent variables namely GDP growth, openness and investment into the external debt model. Our proposed modeling framework follows the econometric specification used by the previous external debt-military expenditure literature. The explanatory variables of external debt that have been chosen in the previous studies are summarized in Table 1 . Following most of the prior papers on this subject ${ }^{1}$, we augment the bivariate model of external debt and military expenditure with GDP growth variable. And following Karagöl (2006) and Shahbaz et al. (2013), we added investment variable (for which we used fixed capital formation data) in our model. Finally, we estimated the following model:

$\mathrm{EXDGDP}_{i t}=\alpha_{0 i}+\alpha_{1 i}$ MLXGDP $_{i t}+\alpha_{2 i}$ GDPGR $_{i t}+\alpha_{3 i}$ FCPFRGDP $_{i t}+\alpha_{4 i} \mathrm{OPNNSS}_{i t}+\varepsilon_{i t}$

where,

EXDGDP $=$ External debt as a share of GDP

MLXGDP = Military expenditure as a share of GDP

GDPGR = Annual growth of GDP

FCPFRGDP = Gross fixed capital formation as a share of GDP

OPNNSS $=$ Exports plus imports as a share of GDP

$\varepsilon=$ is the error term with the conventional statistical properties

As Dunne et al. (2004a) stated as well, in developing the model of military expenditure and external debt, our purpose is not to provide a complete explanation for the development of external debt, but to recognize the specific effects of military expenditure

\footnotetext{
${ }^{1}$ As can be observed from Table 1, all of the reported papers - except the ones using bivariate models- include GDP/ GDP growth variable into their external debt- military expenditure models.
} 
on external debt, given the capacity of the economy to finance the debt. EXDGDP, MLXGDP, OPNNSS and FCPFRGDP are generated by proportioning the current values of series to the current $G D P^{2}$. GDPGR indicates the percentage change in the constant value of Gross Domestic Product $(2005=100)$. The empirical analyses are carried out by the use of annual datasets from The World Bank and Stockholm International Peace Research Institute (SIPRI) (for military expenditures).

As mentioned before, the specification of the independent variables is based on the prior external debt-military expenditure literature. An increase in military expenditure is expected to affect external debt positively. The general idea in the recent literature is that: If a country imports arm equipment and finances import payments by external resources, then due to the lack of foreign exchange reserves, the country relies on foreign borrowings which in turn increases external debt (Shahbaz et al., 2013: p. 5). Overall evaluations of the recent empirical studies give support to the positive impact of military expenditure on external debt, thus the expectations of this study are consistent with the results of the evaluations made on recent studies in the literature.

The impact of income on external debt may be either positive or negative. It depends on whether the growth in income is a result of consumption expenditure or capital expenditure. If the source of the income growth is capital investment, the increase in income will reduce external debt, since capital investment produces additional revenue for government and it allows the government to pay off the debts. However, if the rise is a result of consumption expenditure, the rise in income will also increase external debt; because, consumption expenditure consists of high import content that result in current account imbalances. Thus, the country needs to borrow to meet the imbalances (Narayan and Narayan, 2008: p. 81). Furthermore, it is seen that Smyth and Narayan (2009) used GDP as a proxy for a country's capacity to engage in international borrowing. In addition, Wolde-Rufael (2009: p. 428) explains his reason for the inclusion of GDP into the model as to test whether GDP growth helps countries to pay off their debts. He also stresses the possibility of a positive effect of GDP growth on external debt due to the reality of more income may increase the propensity of governments to spend more on defence. The effect of investment on external debt is expected to be negative. Since investment allows the country to collect additional resources that can be used to pay off external loans, an increase in investment will decrease external debt (Shahbaz et al., 2013: p. 5). Finally, openness is selected as the last determinant of external debt. This variable demonstrates to what extent a country is open to foreign trade. Open economies are expected to borrow more amounts that results in more external debt accumulation over time. In this study, the relationship between external debt and military expenditure is investigated by using annual panel data for 36 developing countries that are Albania, Armenia, Azerbaijan, Belarus, Bolivia, Brazil, Bulgaria, Cameroon, China, Colombia, Dominican Republic, Egypt, Arab Rep., El Salvador, Georgia, Ghana, Guatemala, India, Jordan, Kenya, Lebanon, Macedonia, FYR, Malaysia, Mexico, Morocco, Pakistan, Paraguay, Peru, Philippines, Romania, Senegal, South Africa, Sri Lanka, Thailand, Tunisia, Turkey and Ukraine. The

\footnotetext{
${ }^{2}$ Dunne et al. (2004b) has also used the data by proportioning to GDP value.
} 
sample period covers the years of 1996-2013. The referred 36 countries are selected through three criteria. Firstly, we take into account both IMF's "Emerging \& Developing Economies" classification and The World Bank's "Lower \& Upper Middle Income" classification while determining the countries of interest. Secondly, we used "Political Stability/Absence of Violence" criteria from "The World Bank's Governance Indicators". For this indicator, " $<50$ " shows worse ratings and all countries mentioned above are also chosen for their low percentiles. Lastly, we try not to choose countries from OPEC and too small-sized countries. Country dataset is strongly balanced and sample period covers the years between 1996 and 2013.

\subsection{Estimation Method}

We will utilize "Pooled OLS Model" and "Dynamic Panel Estimation" methodologies to analyze the effects of military expenditure on external debt. Theoretically, panel data analysis is the estimation of economic relationships by using cross sectional time series data where we have repeated observations, i.e. time series of observations, for each individual rather than havening them on an aggregate level (Greene, 1997).

The pooled OLS model estimates a basic regression model as presented in Equation (2):

$$
\mathrm{Y}_{i t}=\alpha+\beta^{\prime} \mathrm{X}_{i t}+\varepsilon_{i t}
$$

In this model; $X_{i t}$ represent the explanatory variables, while t represents the duration and $i$ represents the dimension of the country. This model assumes that all parameters are same for each country (Dunne et al., 2004b: p. 129). This first step of our empirical analysis will give us general clues about the relationship between external debt and our independent variables. There are also other complex solutions available for understanding the relationship between external debt and military expenditures. For a long year data set, it is appropriate using 'static panel' modeling. Or in other words, fixed and random effect models. ${ }^{3}$ For this study, due to time and space limitations -because of small $T$ (not longer than 20 years)-, it would be wise using dynamic modeling instead of the static one (Eberhardt: 2011: p. 7).

Dynamic panel model estimates a model as presented in Equation (3):

$Y_{i t}=\alpha_{i}+\beta X_{i t}+\lambda Y_{i t-1}+\mu_{i t}$

This equation includes a lagged dependent variable as an explanatory variable. As our data has no blank pages and it is strongly balanced, "Dynamic Panel Estimation" method is

3 The selection among fixed effect or random effect model usually depends on the relation between the effects and explanatory variables. If effects are not related to explanatory variables, then random effects estimator is consistent and efficient, whereas fixed effect estimator is also consistent but not efficient. If the effects are related to explanatory variables, fixed effects estimator is consistent and efficient, and random effects estimator is inconsistent (Baltagi et al., 2003). Hausman test is utilized in order to make a selection between fixed effects and random effects. Random effects are chosen over fixed effects if justified by a Hausman test, or if fixed effect estimates are precluded due to the presence of time-invariant variables. 
preferred to observe the variables. Not only for its technical features, it is also a good method for the "small T (time periods)" panel models.

Some econometric problems may arise in panel data estimations. These can be listed as follows (Mileva, 2007):

1. Endogenous variable may be correlated with the error term due to the probability of causality running between $\mathrm{x}$ and $\mathrm{y}$.

2. Time-invariant country characteristics (fixed effects), that are contained in the error term, may be correlated with the explanatory variables.

3. The lagged dependent variable, existing in the model as an independent variable, boosts autocorrelation.

4. A short time dimension and a larger country dimension of the panel data set create problems in estimations.

In case of observations performed on samples with small numbers of time series, there is an alternative approach to study with the dynamics. This method allows a dynamic specification in differences, with a lagged dependent variable. Adaptation of an instrumental variable method is essential in this approach, since differencing induces a bias in the coefficient on the lagged dependent variable, due to the correlation between it and the unobserved fixed effects in the residual. In order to get unbiased and consistent estimates of the coefficients, Arellano and Bond (1991) generalized the method of moments (GMM) technique that uses lags of the endogenous variables $t-2$ and earlier as instruments (Dunne et al., 2004b: p. 129). Two different methods can be chosen to make estimations by using GMM. These are so called "difference" and "system". Because of the shortcomings of "difference GMM", a new estimator called "system GMM" is introduced by Blundell and Bond (1998). The regression in differences and the regression in levels are combined by this estimator. Since Arellano and Bond's (1991) difference GMM estimator has poor finite sample properties and is downward biased when $T$ is relatively small, system GMM is accepted superior in comparison with difference GMM. Hansen Test provides information for making decision whether to apply difference or system GMM. System GMM is chosen over difference GMM if Hansen tests suggest that the instruments are valid, otherwise difference GMM would be implemented.

\section{EMPIRICAL RESULTS}

Estimation results of Pooled OLS Model are submitted in Table 2. When we look through the military expenditure -as our concentration focuses mostly onto this variable in this study-, it can be clearly seen that a change in military expenditure ratio affects external debt positively and statistically significantly in the developing countries of interest. The empirical results indicate that GDP growth creates a significant and negative impact on external debt. ${ }^{4}$ The impact of investment on external debt is found to be significantly

\footnotetext{
4 As far as we know from the literature of financial liberalization, this interaction was weakened by globalization process because of the changes in the definitions and the facts of economics. It is known that the impact of GDP on external debt is decreasing for most of the developing countries, for the last ten years (as it is similar in our empirical findings). However, also making healthy
} 
negative. Furthermore, the results suggest that openness has a positive effect on the share of external debt in GDP. All these empirical evidence are in line with theoretical expectations.

Table 2: Estimation Results of Pooled OLS Model (Robust)

\begin{tabular}{|lc|}
\hline & $\begin{array}{c}\text { EXDGDP } \\
\text { (Dependent Variable) }\end{array}$ \\
\hline MLXGDP & $.0477672^{* * *}$ \\
GDPGR & $(5.99)$ \\
& $-.0091827^{* * *}$ \\
FCPFRGDP & $(-4.03)$ \\
& $-.0083806^{* * *}$ \\
OPNNSS & $(-6.57)$ \\
& $.0027601^{* * *}$ \\
CONS & $(9.73)$ \\
F Test $p$ value & $.360036^{* * *}$ \\
N obs & $(10.63)$ \\
Number of & 0.0000 \\
countries & 648 \\
Min obs & 36 \\
Max obs & 18 \\
Average obs & 18 \\
\hline
\end{tabular}

Note: $* * * * *, *$ indicates statistically significant variables at $1 \%, 5 \%$ and $10 \%$ significance level respectively. _CONS represents constant term, $\mathrm{N}$ obs represents number of observations, $\mathrm{F}$ represents F-test (that tests statistically significance of parameters) and Prob $>\mathrm{F}$ values. Figures in the parentheses are t-statistics.

Empirical findings from Arellano-Bond Dynamic Panel Analysis are presented in Table 3. The results demonstrate that effect of military expenditure on external debt is significantly positive. GDP growth is found to decrease external debt significantly. And the impact of openness is significantly positive. All these findings are consistent with the empirical evidence obtained from pooled OLS model estimations. The impact of investment variable is significantly positive and only this result differs from the findings from previous analysis.

Military expenditure variable seems to be one of the main sources of debt spiral or cycle. In our opinion, it gives a clear message to the debt management and to the creditors that if these countries need more arms or other military equipment, they have to handle much

comparisons between internal and external debt levels are getting harder in the last two decades (See Panizza, 2008). When financial integration, capital flows and flights are taken into account, it is not right to consider or call the same traditional differences in mind within this new era. In addition, there are no clear and sharp lines for outer resources; all is determined by marginal utility of their investments. This also means "real investors" may turn into "creditors" in that country from time to time, if it is feasible for them. For example; foreign investors may put the good use of their credits as a stock or bond in the developing countries, instead of using them as a part of FDI. For similar kind of reasons (more than twenty years), identifying and classifying external resources in developing countries are getting more difficult (See Williamson and Mahar, 1998; Laurenceson, 2002; Bekaert et al., 2005; Ranciere et al., 2006; Reinhart and Rogoff, 2008). 
more debt. As it can be seen in Table 2 and Table 3, military expenditure causes external debt to increase. This finding is in line with our expectations. However, it is important to note that higher levels of debt, especially in developing countries, are risky in structural means. ${ }^{5}$ Similarly, deterioration in fixed capital formation may cause negative effect on the dependent variable, too. On the contrary, trade and financial integration -which is also reflected in openness-, are getting higher levels in time that creates a way for the new external resources.

Table 3: Arellano-Bond Dynamic Panel Estimates (Two-Step System GMM)

\begin{tabular}{|c|c|}
\hline & $\begin{array}{c}\text { EXDGDP } \\
\text { (Dependent Variable) }\end{array}$ \\
\hline EXDGDP L1. & $\begin{array}{c}.9084621^{* * *} \\
(120.39)\end{array}$ \\
\hline MLXGDP & $\begin{array}{c}.0076807^{* * * *} \\
(8.58)\end{array}$ \\
\hline GDPGR & $\begin{array}{c}-.0070073^{* * *} \\
(-22.43)\end{array}$ \\
\hline FCPFRGDP & $\begin{array}{c}.0009358^{* * * *} \\
(6.12)\end{array}$ \\
\hline OPNNSS & $\begin{array}{c}.0003206^{* * *} \\
(11.17)\end{array}$ \\
\hline _CONS & $\begin{array}{c}.0103696 * * \\
(2.66)\end{array}$ \\
\hline $\begin{array}{l}\text { Arellano-Bond } A R(1) \text { test } p \\
\text { value }\end{array}$ & 0.000 \\
\hline $\begin{array}{l}\text { Arellano-Bond } A R(2) \text { test } p \\
\text { value }\end{array}$ & 0.716 \\
\hline Hansen test $\chi^{2} p$ value & 1.000 \\
\hline$F$ Test $p$ value & 0.000 \\
\hline $\mathbf{N}$ ins & 157 \\
\hline N obs & 612 \\
\hline Number of countries & 36 \\
\hline Min obs & 17 \\
\hline Max obs & 17 \\
\hline Average obs & 17 \\
\hline
\end{tabular}

Note: $* * *, * *, *$ indicates statistically significant variables at $1 \%, 5 \%$ and $10 \%$ significance level respectively. CONS represents constant term, $\mathrm{N}$ obs represents number of observations, $\mathrm{N}$ ins represents number of instruments, $\mathrm{F}$ represents F-test (that tests statistically significance of parameters) and Prob $>\mathrm{F}$ values. Figures in the parentheses are t-statistics.

When we deeply examine the dynamic panel estimates, first of all, we have to control whether $A R(1)$ and $A R(2)$ tests are reasonable or not. ${ }^{6}$ Then, Hansen J statistics (an

\footnotetext{
${ }^{5}$ Not far in history, developing world had faced economic problems like debt overhang, rescheduling and reliefs. Due to the lessons from those experiences, it is a well-known fact that debt may have some 'bad taste' on that countries' realities with its future conflicts (along with other socioeconomic problems). Nowadays, fiscal policy mechanisms may warn us about that countries must not tie themselves only to the external resources.

${ }^{6}$ The first test examines the assumption that the error term is not serially correlated. As this test uses the differenced error term by construction AR(1), it is expected to be presented. Therefore, the Arellano-Bond test for autocorrelation determines whether
} 
extension of the Sargan-test statistics to include a robust error structure) allows us to test whether instruments are valid. ${ }^{7}$ Both of these tests indicate that our model is consistent and the results are similar, but there is an inverse relationship in FCPFRGDP with others. According to the coefficients, this variable affects external debt not as powerful as MLXGDP or GDPGR variables do. However, with a strongly (full) balanced panel as ours, it might occur either from the "loss of the one year observation of dynamic modeling" for each country and variable or from the "dynamics of continuous measurement plus the role of external impacts" on this instrument. ${ }^{8}$ As far as we know from the estimation results of Pooled OLS model, external debt is mostly influenced by MLXGDP. It is also same as here in the dynamic one, too. Military expenditures affect external debt through the same direction with the statistically significance level of $1 \%$. The consistent accompaniments of GDPGR in a negative relationship and OPNNSS in a positive way are something to attract the attention. The significance levels of all these variables are $1 \%$, both in OLS and GMM models. With the exception of its sign (which is negative in OLS model), FCPFRGDP also has a high significance level (1\%) according to its relationship with external debt in the dynamic model. By examining all the estimations separately with their sub-segments, the pooled OLS estimation (with robust error terms) gives us the clue of a strong statistical relationship between our independent variables and external debt. Moreover, it is seen that the significance levels of all variables are so high. As it is mentioned in the theoretical part of this study when time and space balance taken into account, we should also investigate the 'dynamic sightseeing' of these variables. In Table 3 , it can be seen from the estimates that reliable and robust scores are obtained (because of the $\chi^{2}$ and $p$ values). It is possible to interpret from these results that all variables are statistically significant and their signs are all as same as (except fixed capital formation) the pooled OLS model. Both OLS and GMM regressions show that military expenditure and GDP affect external debt relatively more than the other variables.

\footnotetext{
the differenced error term has second-order, or higher serial correlation. Under the null hypothesis of no second-order serial correlation, the test has a standard-normal distribution (Curutchet, 2006: 44).

${ }^{7}$ The second assumption is corroborated by a test of over-identifying restrictions, which tests the overall validity of the instruments. Specifically, we use the Hansen J statistics, which is the minimized value of two-step GMM criterion function. Under the null hypothesis of the validity of the instruments, this test has a $\chi^{2}$ distribution with $(J-K)$ degrees of freedom, where $J$ is the number of instruments and $\mathrm{K}$ is the number of regressors. As the two-step estimates of the standard errors are asymptotically more efficient than the one-step variant and $A R(1)$ and $A R(2)$ test $p$ values are reasonable, this statistics is preferred over Sargan, because it is robust to heteroskedasticity and autocorrelation (See Alt and Lassen, 2005: 15; Curutchet, 2006: 44-45; Lopez et al., 2011: 6)

8 Even with a low probability (because of the data provider source of our study), 'one more note' in mind about "statistical causality" or "non-optimality" should be helpful for every researcher. In their study, Maddala and Wu (2000) pointed out the quality of the data problem of developing countries by saying that: "Once, we go beyond developed nations, the data are of very poor quality (and in many cases non-existent)... Most of the data are constructed by interpolation and extrapolation" (Maddala and Wu, 2000: 641).
} 


\section{CONCLUSION}

In this study, panel estimates for the sample of 36 "specially-chosen" developing countries for the time period of 1996-2013 points out that military expenditure has a statistically significant and positive impact on external debt. This positive relationship between military expenditure and external debt is consistent with both theoretical expectations and the empirical results of previous researches in the relevant literature. Our findings put forth that an increase in military expenditure results in an increase in external debt. With these countries' deep risk perception, military expenditures may not be seen as an extraordinary phenomenon for policymakers. On the other hand, this kind of public expenditures can make the defence system of a country more powerful for a foreseeable time period in the exchange of creating more vulnerable economy. As a conclusion, these expenditures constrain the budgetary actions of governments, which also give a rise to inapplicable/inefficient public policies for today and the future.

Our empirical results show that military expenditure, as one of the most important expenditure items in the central government budgets, affects future economic performance through its positive impact on the level of external debt. The main policy implication is that the decision makers should not ignore the need to reduce military expenditure in resolving the external debt problem. If the governments were able to decrease public expenditure related to military, the resources released would be shifted to more productive areas which are stimulative for countries' economic growth and hence the external debt stock could be reduced.

\section{REFERENCES}

Ahmed, A. D., 2012, "Debt Burden, Military Spending and Growth in Sub-Saharan Africa: A Dynamic Panel Data Analysis", Defence and Peace Economics 23(5), 485-506.

Alt, J. E. and D.D. Lassen, 2005, "The Political Budget Cycle is Where You Can't See it: Transparency and Fiscal Manipulation", EPRU Working Paper Series 6.

Arellano, M. and S. Bond, 1991," Some Tests Of Specification for Panel Data Models: Monte Carlo Evidence and an Application to Employment Equations", Review of Economic Studies 58(2), 277-297.

Baltagi, B. H., G. Bresson and A. Pirotte, 2003, "Fixed Effects, Random Effects or HausmanTaylor? A Pretest Estimator", Economics Letters 79, 361-369.

Bekaert, G., C.R. Harvey and C. Lundblad, 2005, "Does Financial Liberalization Spur Growth?", Journal of Financial Economics 77, 3-55.

Bundell, R. and S. Bond, 1998, "Initial Conditions and Moment Restrictions in Dynamic Panel Data Models", Journal of Econometrics 87, 115-143. 
Curutchet, A.S., 2006, "Essays on Fiscal Policy, Public Debt and Financial Development", Lund University-Sweden, Economic Studies 136.

Dunne, J. P., S Perlo- Freeman and A. Soydan, 2004a, "Military Expenditure and Debt in South America", Defence and Peace Economics 15(2), 173-187.

Dunne, J. P., S. Perlo- Freeman and A. Soydan, 2004b, "Military Expenditure and Debt in Small Industrialised Economies: A Panel Analysis", Defence and Peace Economics 15(2), 125-132.

Eberhardt, M., 2011, "Panel time-series Modeling: New Tools for Analyzing xt Data", UK STATA Users Group Meeting, Cass Business School, London, [Online] at http://www.stata.com/meeting/uk11/abstracts/UK11_eberhardt.pdf

Greene, W. H., 1997, "Econometric Analysis", 3rd Edition. New Jersey: Prentice Hall.

IMF, International Monetary Fund Database, [Online] at http://www.imf.org/external/data.htm.

Karagol, E., 2005, "Defence Expenditures and External Debt in Turkey", Defence and Peace Economics 16(2), 117-125.

Karagol, E., 2006," The Relationship Between External Debt, Defence Expenditures and GNP Revisited: The Case Of Turkey", Defence and Peace Economics 17(1), 47-57.

Karagol, E. T. and A. Turhan, 2008, "External Debt, Defence Expenditures and Political Business Cycles In Turkey", Defence and Peace Economics 19(3), 217-224.

Laurenceson, J., 2002, "External Financial Liberalization and Foreign Debt in China", Discussion Papers No. 304, School of Economics, University of Queensland, Australia, 1-21.

Lopez E., V. Riquelme and E. Munoz, 2011, "Long Term Interest Rate and Fiscal Policy", Central Bank of Chile, Working Papers No. 633.

Maddala, G. and S. Wu, 2000, "Cross-Country Growth Regressions: Problems of Heterogeneity, Stability and Interpretation", Applied Economics 32, 635-642.

Mileva, E., 2007, "Using Arellano-Bond Dynamic Panel GMM Estimators in Stata: Tutorial With Examples Using Stata 9.0", Fordham University.

Narayan, P. K. and S. Narayan, 2008, "Does Military Expenditure Determine Fiji's Exploding Debt Levels?", Defence and Peace Economics 19(1), 77-87.

Panizza, U., 2008, "Domestic and External Debt in Developing Countries", [Online] at http://www.unctad.org/en/docs/osgdp20083_en.pdf. 
Ranciere, R., A. Tornell, and F. Westermann, 2006, "Decomposing the Effects of Financial Liberalisation: Crises vs. Growth", NBER Working Papers No. 12806.

Reinhart, C.M. and K.S. Rogoff, 2008, "This Time Is Different: A Panoramic View of Eight Centuries Of Financial Crises", NBER Working Papers No. 13882.

Sezgin, S., 2004, "An Empirical Note on External Debt and Defence Expenditures In Turkey", Defence and Peace Economics 15(2), 199-203.

Shahbaz, M., M. S. Shabbir and M. S. Butt, 2013, "Does Military Spending Explode External Debt in Pakistan?", Defence and Peace Economics, DOI: 10.1080/10242694.2012.724878.

SIPRI, Stockholm International Peace Research Institute Database, [Online] at http://www.sipri.org/research/armaments/milex/milex_database.

Smyth, R. and P. K. Narayan, 2009, "A Panel Data Analysis of The Military ExpenditureExternal Debt Nexus: Evidence From Six Middle Eastern Countries", Journal of Peace Research 46(2), 235-250.

Williamson, J. and M. Mahar, 1998, "A Survey of Financial Liberalization", Essays in International Finance, No. 211, Princeton University, New Jersey.

Wolde-Rufael, Y., 2009, "The Defence Spending-External Debt Nexus in Ethiopia", Defence and Peace Economics 20(5), 423-436.

World Bank, World Bank Database, [Online] at http://data.worldbank.org.

Zaman, K., Q. S.Mahmood, M.M. Khan and A. Rashid, 2012, "An Empirical Investigation of External Debt-Military Expenditure Nexus in Bangladesh", Economia. Seria Management 15(1), 173-188. 
Appendix 1. List of Developing Countries Used in Panel Data Analysis

\begin{tabular}{|c|c|}
\hline Albania & Kenya \\
\hline Armenia & Lebanon \\
\hline Azerbaijan & Macedonia, FYR \\
\hline Belarus & Malaysia \\
\hline Bolivia & Mexico \\
\hline Brazil & Morocco \\
\hline Bulgaria & Pakistan \\
\hline Cameroon & Paraguay \\
\hline China & Peru \\
\hline Colombia & Philippines \\
\hline Dominican Republic & Romania \\
\hline Egypt, Arab Rep. & Senegal \\
\hline El Salvador & South Africa \\
\hline Georgia & Sri Lanka \\
\hline Ghana & Thailand \\
\hline Guatemala & Tunisia \\
\hline India & Turkey \\
\hline Jordan & Ukraine \\
\hline
\end{tabular}

